\title{
The Diversification Use of Melinjo (Gnetum gnemon) in Banten Local Food
}

\author{
*Evi Amelia \\ *Department of Biology Education \\ University of Sultan Ageng Tirtayasa \\ Serang, Indonesia \\ *evi.amelia@untirta.ac.id
}

\author{
Indria Wahyuni \\ Department of Biology Education \\ University of Sultan Ageng Tirtayasa \\ Serang, Indonesia \\ indriasudarman@gmail.com
}

\author{
Pipit Marianingsih \\ Department of Biology Education \\ University of Sultan Ageng Tirtayasa \\ Serang, Indonesia \\ p_marianingsih@untirta.ac.id
}

\begin{abstract}
Melinjo (Gnetum gnemon) is a very potent plant because many of its parts, like leaves, flowers, and seeds, can be useful for culinary purposes. This study aims to explore and inventory the use of melinjo (Gnetum gnemon) in Banten Province, specifically the use in Banten local food. The research was carried out through interviews, field observations, and reference studies to obtain data on the use of melinjo in Banten. The interviewee's sample was conducted using purposive and snowball sampling techniques. Based on the results showed melinjo in Banten used as a food source in making vegetables, fresh vegetables, side dishes, complementary protein food, chili sauce or paste, chips, and crackers, also pastries and snacks. Furthermore, the method of processing melinjo in Banten local food was sautéed, boiled, steamed, fried, roasted, and pounded, with the most dominating way is by sautéing it because of food products made from melinjo mostly processed as vegetables.
\end{abstract}

Keywords: Banten, diversification, Gnetum gnemon, local food, melinjo

\section{INTRODUCTION}

Melinjo (Gnetum gnemon) is a Gymnosperm, a native plant in Indo-Malaya, and often found in Indonesia [1]. Melinjo in Indonesia grows in forest, garden, or even at home yard [2]. Local names of melinjo are very diverse, such as ki tangkil, melinjo, sake, tangkil (Sundanese); bagu, eso malinjo, tangkil, grintul (Java); mulieng (Aceh); manenjo, maninjo (Sumba); and bagu, Poko Sumba (Makassar) [3]. These varieties of local names showed that melinjo is known in almost all regions in Indonesia, including in Banten. Based on data, Banten is one of the six biggest provinces which are producing melinjo [4].

Melinjo is one of the local commodities that has much utilization [5]. Many of its parts, including leaves, flowers, and seeds, can be useful for many purposes [6], for instance, on local food. Based on interviews with Banten people, melinjo plants are known to be commonly used by locals as cooking ingredients such as vegetables, seed chips, and seed coat chips. It indicated that melinjo plants have many potentials to be utilized. Variation or diversification of the use and method of processing melinjo as local food in Banten needs to explore so that the people can further enhance the potential of melinjo itself.

Food diversification is essential in supporting food security. Diversification is an effort to diversify food consumption, including to change people's consumption patterns, so that people will consume more types of food with adequate, balanced and safe nutrition [7] [8] [9]. Furthermore, the efforts to establish food security require strengthening the pillars of local resource-based food security so that they are not susceptible to the influence of external factors that threaten the stability of food availability and access to food [7]. Thus, this study aims to explore and to inventory the use of melinjo (Gnetum gnemon) in Banten local food as well as its processing methods, which can support the diversification and food security in Banten.

\section{METHODS}

The locations used in this study cover 8 regions in Banten Province, including four districts and four cities: Serang district (Mancak, Ciomas, Padarincang subdistricts); Pandeglang district (Mandalawangi, Jiput, Majasari subdistricts); Lebak district (Cibeber, Malingping, and Gunung Kencana subdistricts); Tangerang district (Rajeg, Pasar Kemis subdistrict), Serang city (Curug, Cipocok Jaya, Taktakan, Serang subdistricts), Cilegon city (Grogol, Purwakarta, Jombang subdistrict), Tangerang city (Batu ceper, Paris gaga, Karawaci subdistrict), and South Tangerang city (Situ subdistrict). The population in this study were all districts and cities in Banten Province. The sample is the people who know and can provide information about the use of melinjo in Banten. Sample selection is made by using purposive and snowball sampling techniques [10]. As for the tools and materials used in this study include interview questionnaires, observation sheets, cameras, recorders, and stationery.

The research was carried out through several stages, including interviews, field observations, and reference studies. In the interview stage, the data collection conducted through semi-structured interviews by asking several questions listed in the interview guidelines. It aims to obtain data about local names, parts of the plant that used for food, uses, and processing methods. Respondents were selected based on purposive sampling and snowball sampling techniques. Then, field observations are conducted to verify data and information previously obtained through interviews and to explore even more data and information regarding the potential and utilization of melinjo found in the field. The observation was carried out by documenting the parts of melinjo plants that used for local food as well as the processing methods by the Banten people. Reference studies are taken on by reviewing other references to support data and information collected from interviews and field 
observations. All the data obtained were analyzed descriptively.

\section{RESULT AND DISCUSSION}

The result showed melinjo used as a food source in all four cities and four districts in Banten. The people use melinjo in making vegetables, fresh vegetables, complementary protein food, chili sauce or paste, chips and crackers, also pastries and snacks (Fig. 2). Melinjo can be used as a food source because it contains quite high nutrients, such as carbohydrates, fats, proteins, minerals, and vitamins [2].

The use of melinjo as a vegetable is the most widely used in the Banten local food. People in Southeast Asia generally recognize melinjo as a vegetable crop [11]. The use of melinjo in Banten local food into vegetables is quite diverse, and it can be processed into vegetables without the addition of other vegetables, or mixed with other vegetables. Furthermore, leaves, seed coats, or flowers of melinjo (Fig. 1) can be used as the main ingredient in making vegetables, but in general, the Banten people use melinjo as a mixture of vegetables. It is because the use of colorful vegetables and variants in vegetables can provide different and more benefits for health. Consuming vegetables that contain various types of vegetables can also provide an exciting flavor [12].

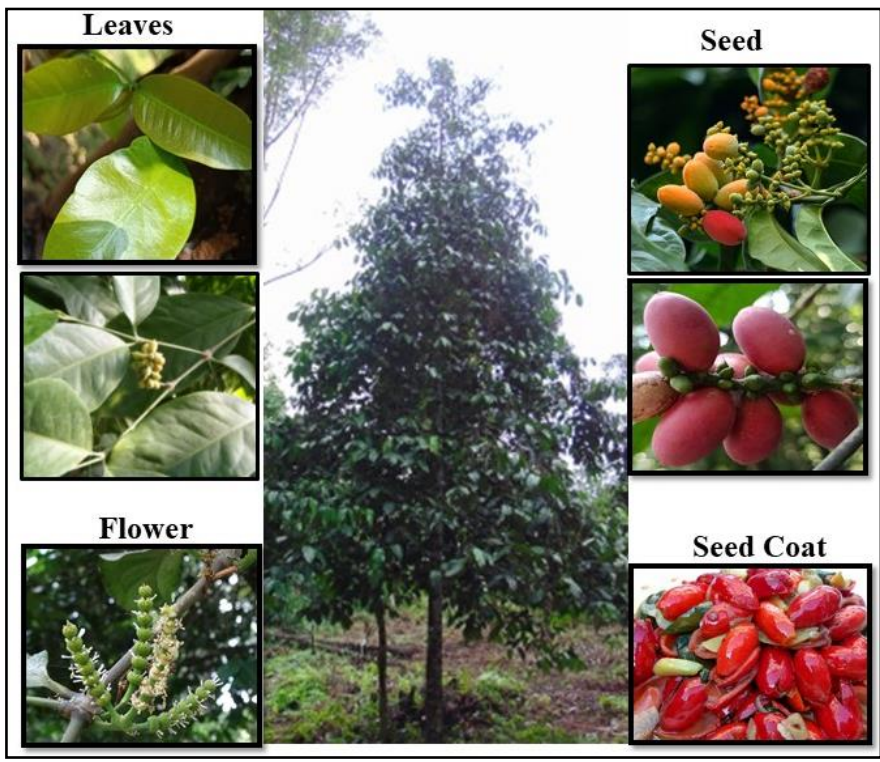

Fig 1. Melinjo (Gnetum gnemon) tree

In Banten, melinjo seed coat, leaves, or flower, each of them can be processed into sautéed vegetables. Additionally, melinjo can be processed mixed with any others vegetable, such as sayur asem (sour vegetables soup), lodeh (mixed vegetables in coconut milk soup), sayur bening (vegetables with clear soup or lightly seasoned soup), sayur lada (vegetables with spicy soup), sambelan kulit tangkil (melinjo seed coat mixed with other vegetables), burog sambal (melinjo seed coat mixed long beans), gudeg (young unripe jack fruit stewed for several hours with coconut milk), jelgudeg (melinjo flower mixed with grated young coconut), mugana vegetables (melinjo flowers add by mugana "roasted coconut") (Fig. 2). Processing vegetables usually contain soup with varies seasonings depending on the desired taste. A vegetable can be processed by boiling, steaming, or sautéing, as the most widely used method for processing melinjo vegetables in Banten. The sautéing process performed only to use a little oil and soup.

Meanwhile, the boiling process is done by heating vegetables in a soup like water, coconut milk, or broth. Furthermore, based on Tab. 1, not all kinds of melinjo vegetables are found in all regions in Banten, people in a particular region only prepare some dishes. As a case in point, sayur sambelan kulit tangkil and burog sambal (both are melinjo seed coat dish mixed with other vegetables) only exist in Serang and Cilegon City. Those served as a typical dish during the Muslim holy day or in a particular celebration. Jelgudeg and mugana, sequentially only found in Cilegon and Lebak. Melinjo is a dish on Banten's local food that can also be used as fresh vegetables as done by the People in Lebak District. Fresh vegetables that consumed in raw or cooked by boiling or steaming serve as a complement to the leading food [13] and also usually eaten with chili sauce. People in Lebak district commonly eat fresh vegetables from steamed melinjo leaves with tomato sauce or shrimp paste sauce to add flavor to the dish.

The use of melinjo in Banten local food also as a complementary for protein food. The Banten people usually add leaves or flowers of melinjo, as a mixture of ingredients, in dishes such as salted-fish pepes (salted fish processed by using banana leaf as food wrappings and then steamed or grilled. Young leaves and flowers of melinjo flowers can be consumed with seafood, such as fish or shrimp [14]. In some parts of the Banten region, like in Tangerang district, melinjo leaves can also be used as additional in the making of tempeh ungkep (steamed of fermented soybeans).

Furthermore, melinjo can also be used as side dishes such as soup porridge, bakwan melinjo leaf (flour with chopped vegetables fritter snack), and cireng tangkil (tapioca fritters adding with melinjo seed coat). Soup porridge is a typical Pandeglang snack made from rice with additional seasonings and vegetables like cabbage, carrots, long beans, bean sprouts, and the most important are melinjo leaf buds. As for, the bakwan leaf melinjo and cireng tangkil is a snack innovation made by the people in Mancak (Serang district) by mixing leaves and seed coats of Melinjo flour batter, then frying it in hot oil. The addition of melinjo leaves in the soup porridge and other snacks intended as a flavor and color.

Sambal (chili sauce or paste) is also an example of processed food that uses melinjo as an additional ingredient. People in the Pandeglang district use melinjo leaves to make melinjo leaf chili sauce. Meanwhile, the melinjo seed coat is used by the people of Cilegon city in making sambal goreng (fried chili sauce). The addition of leaves and melinjo seed coats in these chili sauces is one alternative to eat vegetables as well as a unique way to enjoy the chili sauce. Adding a melinjo seed coat also adds a red color to the chili sauce.

Another use of melinjo as food is to become chips and crackers, such as emping and ceplis (seed melinjo chips), 
melinjo seed coat chips, melinjo leaf chips, and melinjo crackers. Emping is the most famous processed food from melinjo in Banten and as a typical souvenir from Banten Province. The production of emping melinjo in Banten is quite common in Pandeglang, Serang, Lebak, and Cilegon. As a food souvenir, emping products are not only in demand by domestic consumers but have also exported in various countries such as Saudi Arabia, Qatar, and South Korea. It showed that Banten is one of the significant emping producers' regions in Indonesia [15]. Besides emping, melinjo also processed into melinjo seed coat chips. Making that food is quite easy, just by frying soft melinjo seed coat in hot oil until crisp, then seasoned with salty, spicy, or sweet based on desired taste. As for making melinjo leaf chips is done by blending the melinjo leaves in a liquid flour mixture and frying it until crisp. On the other hand, the emping melinjo crackers are deep fried crackers made from starch and other ingredients that serve as a flavoring and sprinkle with emping. More, melinjo chips and crackers food products have also widely marketed, so in turn, it can increase the income of the society.

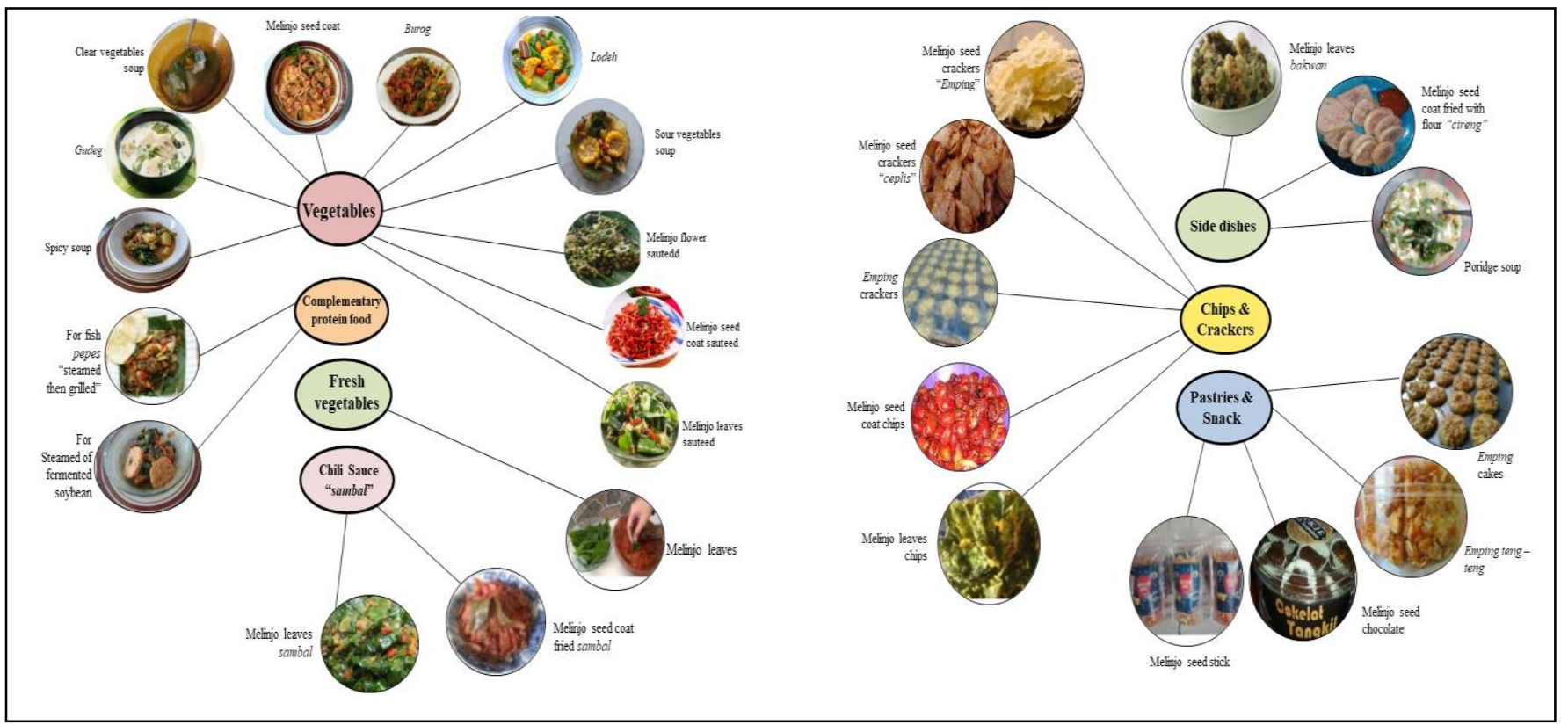

Fig 2. The Use of Melinjo (Gnetum gnemon) in Banten Local Food

Melinjo can also be used in making pastries and snacks such as emping cake, teng-teng emping, chocolate tangkil (melinjo seed chocolate), and tangkil stick (melinjo seed stick). Emping cake is made by mixing the batter cake with crushed emping and then baked in the oven. While teng-teng emping made by mixing crushed emping with caramel sugar. The tangkil chocolate and tangkil sticks are pastries with crushed melinjo seeds as the main ingredients, added with chocolate and then fried.

Melinjo seeds can also be used as flour [16]. The utilization of melinjo seeds into flour is one alternative to extend the shelf life of melinjo seeds. Flour made by melinjo seed then can be processed into various other types of food such as cakes and cookies. However, based on the results of observations and interviews showed that Banten people had not used melinjo into flour because of the less knowledge about it.

The variety of types of food products made from melinjo also causes a variety of ways of processing its product. The method of processing melinjo carried out by Banten people, among others sautéed, boiled, steamed, fried, roasted, and pounded. The most common method of processing melinjo is by sauteing it (Tab. 1) because melinjo mostly processed as vegetables in Banten local food. Processing food by sautéing way serves to maximize the taste from seasonings so that it can increase the flavor of vegetables.

TABLE 1.

UTILIZATION, PROCESSING METHODS, AND REGION IN BANTEN THAT USE MELINJO (Gnetum gnemon) AS FOOD

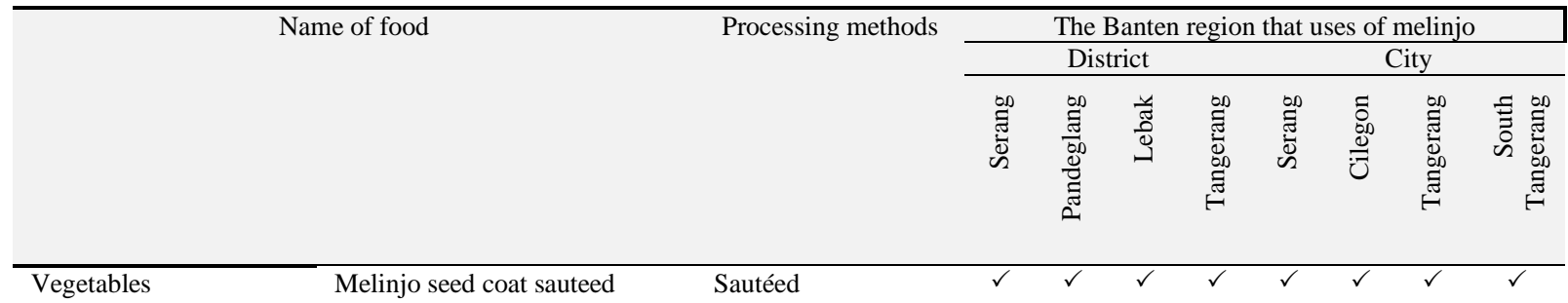




\begin{tabular}{|c|c|c|c|c|c|c|c|c|c|c|}
\hline \multicolumn{2}{|c|}{ Name of food } & \multirow[t]{3}{*}{ Processing methods } & \multicolumn{8}{|c|}{ The Banten region that uses of melinjo } \\
\hline & & & \multicolumn{4}{|c|}{ District } & \multicolumn{4}{|c|}{ City } \\
\hline & & & 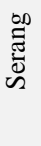 & 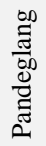 & 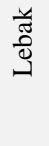 & 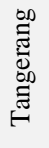 & 䧩 & 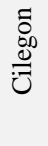 & 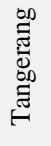 & 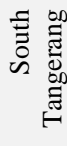 \\
\hline & Melinjo leaves sautéed & Sautéed & $\checkmark$ & $\checkmark$ & $\checkmark$ & $\checkmark$ & $\checkmark$ & $\checkmark$ & $\checkmark$ & \\
\hline & Melinjo flower sauteed & Sautéed & $\checkmark$ & $\checkmark$ & & & $\checkmark$ & $\checkmark$ & & \\
\hline & Sour vegetable soup & Boiled & $\checkmark$ & $\checkmark$ & $\checkmark$ & $\checkmark$ & $\checkmark$ & $\checkmark$ & $\checkmark$ & $\checkmark$ \\
\hline & Lodeh & Boiled & & $\checkmark$ & $\checkmark$ & $\checkmark$ & $\checkmark$ & $\checkmark$ & $\checkmark$ & $\checkmark$ \\
\hline & Clear vegetable soup & Boiled & & $\checkmark$ & $\checkmark$ & & & & & \\
\hline & Spicy vegetable soup & Sautéed & & $\checkmark$ & & & & & & \\
\hline & sambelan kulit tangkil & Sautéed & $\checkmark$ & & & & $\checkmark$ & & & \\
\hline & Sambal burog & Sautéed & & & & & $\checkmark$ & $\checkmark$ & & \\
\hline & Gudeg & Sautéed & & & & & $\checkmark$ & & & \\
\hline & Jelgudeg & Sautéed & & & & & & $\checkmark$ & & \\
\hline & Mugana & Boiled & & & $\checkmark$ & & & & & \\
\hline Fresh vegetables & Steamed Melinjo leaves & Boiled & & & $\checkmark$ & & & & & \\
\hline Complementary protein & For Fish pepes & Steamed & $\checkmark$ & $\checkmark$ & & $\checkmark$ & $\checkmark$ & $\checkmark$ & & $\checkmark$ \\
\hline food & $\begin{array}{l}\text { For steamed of fermented } \\
\text { soybeans }\end{array}$ & Steamed & & & & $\checkmark$ & & & & \\
\hline Side dishes & Porridge soup & Boiled & & $\checkmark$ & & & & & & \\
\hline & Melinjo leaves bakwan & Fried & $\checkmark$ & & & & & & & \\
\hline & Melinjo seed coat cireng & Fried & $\checkmark$ & & & & & & & \\
\hline Chili sauce "Sambal" & Melinjo leaves sambal & Pounded & & $\checkmark$ & & & & & & \\
\hline & Melinjo seed coat fried sambal & Pounded & & & & & & $\checkmark$ & & \\
\hline & Emping & Roasted-Pounded- & $\checkmark$ & $\checkmark$ & $\checkmark$ & $\checkmark$ & $\checkmark$ & $\checkmark$ & $\checkmark$ & $\checkmark$ \\
\hline & Ceplis & fried & $\checkmark$ & $\checkmark$ & $\checkmark$ & $\checkmark$ & $\checkmark$ & $\checkmark$ & $\checkmark$ & $\checkmark$ \\
\hline Chips and Crackers & Melinjo seed coat chips & Fried & $\checkmark$ & $\checkmark$ & $\checkmark$ & $\checkmark$ & $\checkmark$ & $\checkmark$ & $\checkmark$ & \\
\hline & Melinjo leaves chips & Fried & $\checkmark$ & $\checkmark$ & & $\checkmark$ & & & & \\
\hline & Emping Crackers & Fried & & & & & $\checkmark$ & & & \\
\hline & Emping cakes & baked & & & & & & & & $\checkmark$ \\
\hline & Melinjo seed Chocolate & Fried & $\checkmark$ & & & & & & & \\
\hline Pastries and Snacks & Emping teng-teng & Fried & & $\checkmark$ & & & $\checkmark$ & & & \\
\hline & Melinjo seed tick & Fried & & & & & & $\checkmark$ & & \\
\hline
\end{tabular}

\section{CONCLUSION}

Based on the results showed melinjo in Banten local food used for making vegetables, fresh vegetables, complementary protein food, chili sauce or paste, chips and crackers, also pastries and snacks. Furthermore, the method of processing melinjo in Banten local food ware sautéed, boiled, steamed, fried, roasted, and pounded, with the most dominating way, is by sautéing it because of food products made from melinjo mostly processed as vegetables.

\section{ACKNOWLEDGMENT}

We wish to acknowledge and thank to the melinjo exploration teams in Biology Department, Faculty of Teacher Training and Education, University of Sultan Ageng Tirtayasa (UNTIRTA), and especially for Indonesia Centre of Excellence for Food Security (ICEFORY) UNTIRTA, then Islamic Development Bank (IsDB) which have supported and funded this research.

\section{REFERENCES}

[1] E. Kato, T. Yuji, and F. Sakan, "Stilbenoids Isolated from the Seeds of Melinjo (Gnetum gnemon L.) And Their Biological Activity," Agric Food Chem, vol. 57 No. 6, 2009, pp.2544--2549.

[2] H. Sunanto, Budidaya Melinjo dan Usaha Produksi Emping. Kanisius, Yogyakarta, 1991.

[3] H.A. Hariana, Tumbuhan Obat dan Khasiatnya Seri 2. Penebar Swadaya, Jakarta, 2008.
[4] Badan Pusat Statistik (BPS) Indonesia, Statistik Tanaman Buahbuahan dan Sayuran Tahunan. Badan Pusat Statistik Indonesia, Jakarta, 2015.

[5] C. Dewi, R. Utami., and N.H. Riyadi, "Aktivitas Antimikroba Ekstrak Melinjo (Gnetum gnemon L.)", Jurnal Teknologi Hasil Pertanian, vol.5 No.2, 2012, pp.74--81.

[6] M. Ali, A. Wulandari, and S. D. Listianti, Pengendalian mutu pada emping melinjo Ud Intisari Jaya di Yogyakarta Jomblang Palbapang Bantul. https://opensienceframework.io/hvkdb/, 2009.

[7] Sumaryanto, "Diversifikasi sebagai salah satu pilar ketahanan pangan", Forum penelitian agro ekonomi, vol. 27 No. 2, 2009, pp. 93 -108 .

[8] R. Elizabeth, "Strategi Pencapaian Diversifikasi dan Kemandirian Pangan: Antara Harapan dan Kenyataan", Iptek Tanaman Pangan, vol. 6 no. 2, 2011, pp. 230-242., [9] G.S. Hardono, "Strategi Pengembangan Diversifikasi Pangan Lokal". Analisis Kebijakan Pertanian, vol. 12 No. 1, 2014, pp. 1-17.

[10] Riduwan, Belajar Mudah Penelitian untuk Guru, Karyawan dan Peneliti Pemula Cetakan ke-10. Alfabeta, Bandung, 2015.

[11] L. Lingga, Cerdas Memilih Sayuran, Agormedia Pustaka, Jakarta, 2010.

[12] E. Lau, Healthy Express Super Sehat dalam 2 Minggu. PT Gramedia Pustaka Utama, Jakarta, 2009.

[13] H.F.L. Muhammad, and P. Oktaviani, Bebas Kanker Tanpa Daging, Jogja Great Publisher, Yogyakarta, 2010.

[14] T.K. Lim, Edible Medicinal and Non-Medicinal Plants Volume 3 Fruits, Springer, New York, 2012.

[15] Y.D.I.S. Siregar, and P. Utami, "Pemanfaatan Ekstrak Kulit Melinjo (Gnetum gnemon) Sebagai Pewarna Alami pada Pembuatan Lipstik", Jurnal Kimia Valensi, vol.4 No.2, 2014, pp. 98--108.

[16] Alyanti, Patang, and Nurmila, "Analisis Pembuatan Dodol Berbahan Baku Tepung Melinjo dan Tepung Beras Ketan", Jurnal Pendidikan Teknologi Pertanian, vol. 3, 2017, pp. 40-51. 